\section{Kreasjonismen er aldri morsom}

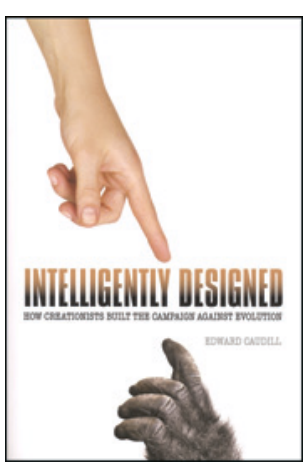

Edward Caudill

\section{Intelligently designed}

How creationists built the campaign against evolution. 200 s. Champaign, IL: University of Illinois Press, 2014. Pris USD 25 ISBN 978-0-252-07952-8

Amerikanerne er verdensledende innen vitenskap. Samtidig tror nesten halvparten av dem at "Gud skapte mennesket i stor grad slik de ser ut i dag, på et tidspunkt for mindre enn 10000 år siden».

Kreasjonismen oppsto i USA tidlig på 1900-tallet. Bevegelsen ble lenge regnet som marginal og kuriøs, men har vokst seg sterk. I dag fremstår den i sin moderne form - «intelligent design» (ID): læren om at verden er designet av en designer. Dette i et forsøk på å gjøre seg lekker for skoleverket. Ingen religion skal favoriseres, men når vi underviser i evolusjon, hvorfor ikke også i «vitenskapen om design»?

I den grad nordmenn vet hva kreasjonisme er, er det forbundet med rettssaken i Dover, Pennsylvania i 2005. Kreasjonistene tapte, men evolusjonen har langt fra vunnet. Journalistprofessor Edward Caudill viser i boken Intelligently Designed - How creationists built the campaign against evolution hvordan det amerikanske samfunnet er under stadige angrep fra konservative, religiøse grupper. Vi nordmenn bør kanskje være mer bekymret over at kreasjonismen nå er i fremmarsj i Europa, ikke minst takket være muslimsk innvandring. Dette lærer du imidlertid ikke noe om - hvis du leser Caudills bok. Du lærer heller ikke hva vitenskap er, eller ikke er, du lærer ikke om evolusjon. Du lærer derimot mye om amerikansk politikk, hvilket antakelig er forfatterens intensjon.

Mennene bak intelligent design forsøker å fremstille det som vitenskap, men er fullt på det rene med at det ikke er det. Dette er utelukkende en politisk bevegelse. Det er det kristenkonservative USA i kamp mot modernismen. En kamp som spiller på amerikanske ideer om personlig frihet, veien mot vest, rebellen mot etablissementet, de undertrykte, de arrogante akademikerne - og Gud. Denne delen av historien håndterer Caudill med stor kompetanse. Det har vært skrevet bøker om dette tidligere, den grundigste er antakelig Forrest \& Gross' Creationism's Trojan Horse fra 2004 - nesten uleselig i sin detaljrikdom. Caudill gir deg det samme, på betydelig færre sider, og med et adskillig bedre språk.

Leseopplevelsen var likevel ikke stor. Jeg fristes til å si «som vanlig». Jeg har et par hyllemeter kreasjonisme i biblioteket. Bare to av bøkene er verdt å lese for andre enn spesielt interesserte i 2006 utga John Brockman antologien Intelligent Thoughts - ikke utfyllende, men lesbar på grunn av bidragsytere som Steven Pinker, Richard Dawkins, Frank Sulloway og Jerry Coyne. Den andre boken du trenger, er Robert Pennocks Tower of Babel fra 1999. Har du lest den, kan du vurdere Edward Caudills Intelligently Designed.

\section{Erik Tunstad}

Høgskolelektor, Avdeling for lærerutdanning Høgskolen i Vestfold

\section{Regionalanestesi i lommeformat}

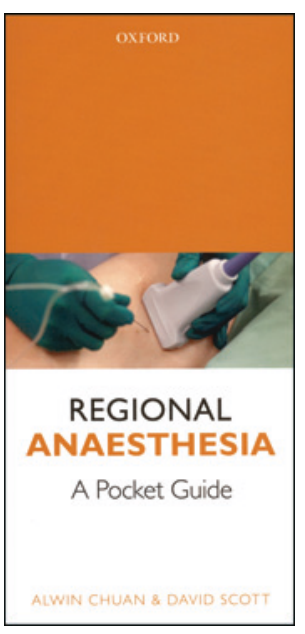

Alwin Chuan, David Scott Regional anaesthesia A pocket guide. 153 s, ill. Oxford: Oxford University Press, 2014. Pris GBP 28 ISBN 978-0-19-968423-6

Dette er en lærebok i lommeformat for anestesileger. Den er kortfattet, muligens for kortfattet for anestesileger som er ferske på feltet. Ultralydteknikk og grunnleggende visualiseringsteknikker («in-plane» versus «out-of-plane») er godt beskrevet.

Farmakologiavsnittet er kort, men presist for et utvalg av lokalanestetika (anslagstid, varighet og dosering). Bivirkninger og komplikasjoner er godt beskrevet, og på den siste siden beskriver forfatterne en god algoritme for behandling av intoksikasjoner med lokalanestetika.

Kapitlene med de ulike kroppsregionene (hode og øvre og nedre ekstremiteter) er bygd opp systematisk og beskriver landemerker, teknikk med bruk av ultralyd og teknikk med bruk av nervestimulator. Boken inneholder et kapittel om paravertebral- og epiduralanestesi og om blokader på torsoen (TAP-blokade (transversus abdominus plane), interkostal blokade med flere).

De anatomiske oversiktsbildene er i noen tilfeller for upresise. Landemerkebildene er gode, men ultralydbildene er relativt mørke, og oppløsningen kunne vært bedre. Det er litt underlig at forfatterne skriver i teksten at prosedyrene skal utføres med sterile hansker og munnbind, men på bildene bruker de verken hansker eller munnbind og har til og med på seg armbåndsur. Steril teknikk skal brukes ved innleggelse av kateter for regionalanestesi.

Kapitlene om blokader på øvre og nedre ekstremiteter er gode. De er kortfattede og presise, og indikasjoner og kontraindikasjoner er beskrevet for alle. De fleste blokadene er med, men noen mangler, f.eks. cervikal pleksusblokade. Forfatterne anbefaler å bruke 20-30 $\mathrm{ml}$ lokalanestetikum ved interskalen pleksusblokade, men nevner ikke tydelig nok at dette volumet oftest vil medføre en ipsilateral phrenicusparese. Det er positivt at supplerende blokader for perifere nerver er beskrevet («rescue block»).

Det er litt underlig at forfatterne omtaler sentrale blokader som torakal blokade og epidural blokade for obstetrisk analgesi og ikke konsentrerer seg kun om perifere nerveblokader. TAP-blokaden er godt beskrevet, men det er ikke nevnt at påliteligheten er omdiskutert i fagmiljøet.

Boken passer fint i legefrakken, men innbindingen er dårlig. Skriftstørrelsen er for liten og begrenser brukervennligheten, og oppløsningen av ultralydbildene er ikke bra nok. Boken omhandler de fleste relevante perifere nerveblokader og anbefales for anestesileger som vil ha en liten huskebok i lommen.

Ulrich Spreng

Hans Schmidt Rasmussen

Anestesileger, Bærum sykehus 